\title{
Developing Fundamental Movement Skills Using Movement Education Models in Elementary School $3^{\text {rd }}$ Grade
}

\author{
Ricky Wibowo*, Widi Wardiana \\ Departemen Pendidikan Olahraga \\ Universitas Pendidikan Indonesia \\ Bandung, Indonesia \\ *ricky_wibowo@upi.edu,widiwrdn@student.upi.edu
}

\begin{abstract}
The purpose of this study was to developing fundamental movement skills (FMS) using movement education models Its used experimental method, pretest-posttest control group design. Third grade elementary school students $(n=150$, boys $=84$, girl $=66$ ) were enrolled in this study. Participants were randomly assigned into two different groups: movement education models and control group using common PE lesson program curriculum and divided in to four classes. FMS was measured by Gross Motor Development-Second Edition (TGMD2). Test consisting of locomotor and control object skills. The Data analyze using independent t-test. The results showed that movement education models learning have a significant effect on FMS.
\end{abstract}

Keywords-movement education; fundamental movement skills; primary school student

\section{INTRODUCTION}

Promoting FMS is an important focus in physical education recently, especially at the lower grade level [1]. Children who master FMS are predicted to have good levels of physical activity and weight control [2-4]. Therefore, it is compulsion that FMS is an important part of physical education in elementary schools. The elementary school curriculum, especially the lower classes, emphasizes being able to master fundamental movements. Because FMS has an important role to play in the future.

Physical activity not only provides an opportunity to expend energy, but also media for the development of FMS. FMS is a concatenation of regular fundamental movements and involves a combination of movement patterns from two or more body part [5]. FMS is the first stage to mastery other movement skills. Long-term studies show that children who have mastered FMS from an early age possess proficiency in later physical activity [5]. So it can be said that FMS is the foundation of children to participate in various physical activities and sports. Other studies have shown that FMS mastery in childhood contributes to the learning and mastery of specific skills needed to participate in physical activity and sports [6]. Besides that, FMS mastery as early as possible is expected to be able to prevent delays in mastering and learning more difficult movements in the future [7]. Therefore, FMS must be applied as early as possible.

In mastering FMS, an understanding of the movement concept is needed. Especially in elementary school age children. At this age child tend to be egocentric both emotionally and socially. At this time student also develop various locomotor, manipulative and stability/balance patterns. Students can learn various forms of movement well if they are capable of exploratory activities by themselves [8]. Learning various movement activities by understanding the movement that is performed. The movement map divides all possible movement maps into five major categories. There are body movements, body awareness, space awareness (where the body moves, qualities of movement (how the body moves, relationships (how the body relates) $[6,9]$.

Movement education is one model of child-oriented physical education teaching and does not emphasize competitiveness. Believed to be applicable to the development of FMS. Movement education is a learning model in physical education that emphasizes teaching concepts and movement components [8]. The results show that movement education must begin in early childhood, and must be maintained as a lifelong activity based on the principle of lifelong learning, because it is emphasized that it is very difficult to obtain a number of skills in the future after the critical period is passed to get it [9]. The results showed that throwing, catching, controlling the ball with legs and arms, and motor skills can be obtained between ages 6 and 7 at the maturity level [9].

This study focuses on how movement education is able to make elementary school students mastery the movement through various experiences of movement activities such as locomotor activity, non-locomotor, body balance, games, relays, dance, fitness experience and sport skills. Physical educators often teach games, sports, or fitness activities without teaching critical movement skills and understanding of movement concepts in Rudolf Laban movement framework [10]. Physical education in elementary school based on the movement concept Laban's focuses primarily on helping students to be movement-skills competency. However, the cognitive and affective domains are also attached to the 
movement education model. In the cognitive domain the teacher designs learning experiences to help develop movement awareness. Students are expected to understand the language of movement [11], how the body moves in various settings of movement activities. In the affective domain, teachers design learning experience to develop mutual respect for themselves by knowing their body's ability to move. And respect for others in their involvement in movement activities in physical education. Knowing his body in movement is expected to be able to foster awareness of keeping his body healthy and active in various physical activities.

Based on the explanation above, the importance of developing FMS needs a serious focus of physical education teacher's education to arrange various settings for appropriate physical activities with children's development. Teaching movement education in children, especially children aged 9 years requires precision in choosing movement activities that are able to foster awareness of children's movement. The purpose of this study was to develop FMS through movement education models in third grade elementary school children or in the 9-year age group.

\section{METHOD}

The research method used in this research is experimental method, using pretest-posttest control group design. This research involves two researchers that roles as teacher and students at elementary school in Bandung, Indonesia. The participants were enrolled in this study is third grade elementary school students $(n=150$, boys=84, girl=66). Participants were randomly assigned into two different groups: movement education models and control group using common $\mathrm{PE}$ lesson program curriculum and divided in to four classes. A total of 150 students, age ranging from $9-10$ years $(9.41 \pm 0.23$, height $(1.51 \pm 0.9)$, weight $(42.5 \pm 0.4)$. One group of 74 students comprised of 42 boys and 32 girls, were divided in to two class given treatment with movement education models and a control group of 76 students consisting of 42 males and 34 girls were divided in to two class, used physical education learning based on the existing curriculum.

\section{A. Instrumentation}

Fundamental movement skills were evaluating using The Test of Gross Motor Development (TGMD-2) of children from 3 - 10 years $[12,13]$. Among the primary goals of the TGMD-2 is to serve as a measurement tool in research involving gross motor development. Locomotors (Loc) skills were defined as running, galloping, hopping on one foot, jumping with both legs, and jumping side-wise. Object control skills (OC) were defined as hitting, bouncing, catching, kicking, throwing and rolling ball. According to Ulrich and Wouter, each child was given two trials for each skill assessment, where scores of both trials were then summed up to obtain a raw score $[14,15]$. The raw scores of the locomotor and object-control skills were added to provide an overall score which was then converted to a percentile score, standardized for age and sex. The construct validity of the TGMD- 2 test for locomotors component is $\mathrm{r}=$ $.68-78$ and for manipulative component $r=.66-.87$. The overall value of Cronbach Alpha test TGMD-2 for each test item range between .82 to .83 . FMS was measure before and after intervention program.

\section{B. Intervention Program}

The research process is divided into three stages. In the first stage of pre-test, the tests performed Test of Gross Motor Development (TGMD-2). After having initial data, it was processed with the provision of learning materials according to physical education in elementary school. One group used a movement education models and a control group used an instructional learning in accordance with existing syllabus. The time for conducting research is on February 27 to April 17, 2018. The implementation stage is the core stage of an instrument in data retrieval, while the implementation phase of the researchers for 14 meetings, the first meeting was held pretest by performing FMS tests using the TGMD-2 instrument and, after which the next meeting took treatment for 12 meetings with movement education learning model, in the last week of the post-test implementation by performing FMS tests using the TGMD-2 instrument.

\section{Statistical Analysis}

All data were analyzed using the Statistical Package for the Social Sciences (SPSS). Descriptive statistics (frequencies, means, standard deviations, ranges) are used to describe the demographic and background information. Using Independent Sample T-test (for parametric data), and Mann Whitney (for nonparametric data) for establishing effect of intervention program toward FMS.

\section{RESULTS AND DISCUSSION}

To find out the results of the measurement of research variables consisting of FMS processed using a statistical approach, so that answers can be known or rejected hypotheses according to the real level proposed. In this section presenting the results of the calculation data processing as it is, according to the data from the research results that the author carried out. The results of processing FMS score data were then analyzed using the Statistical Product and Service Solution (SPSS) computer software program. The following are the results of data analysis on FMS of third grade elementary school students.

TABLE I. DESCRIPTION OF FMS DATA EXPERIMENT AND CONTROL GROUP

\begin{tabular}{|c|c|c|c|c|c|c|}
\hline \multicolumn{2}{|c|}{ Sample Group } & $\mathbf{N}$ & Lowest & Highest & Stad. & t-value \\
\hline \multirow[t]{2}{*}{ Experiment } & Pre & 74 & 17,00 & 33,00 & 4,12 & \multirow[t]{4}{*}{.15} \\
\hline & post & 74 & 41,00 & 68,00 & 3,98 & \\
\hline \multirow[t]{2}{*}{ Control } & Pre & 76 & 18,00 & 32,00 & 3,26 & \\
\hline & post & 76 & 39,00 & 64,00 & 5,34 & \\
\hline
\end{tabular}

For the results of the normality test of the output produced by the SPSS 22 program there is an analysis of the data normality test, namely kolmogorov smirnov, Shapiro-wilk, indicating that the value of probability or significance means that the data of each group in this study are normally distributed. The analysis is based on probability values (Sig.) Which are compared with $\alpha 0,05$ degrees. From the table 
above, the results show that for the experiment (Sig. 0, $200>$ 0,05 ) and control class group (Sig. 0,419>0,05) on pre-test and post-test, the probability value is distributed normal.

The two different test averages used the t-test in this research, the t-test was used to find out the differences in the average score of FMS between the experimental class and the control class. The FMS score is 2.491 with probability (Sig). $0.15<0.05$. This means that, there is a significant difference FMS between the experimental class group and the control class. That it can be concluded that the movement education model has an effect on FMS and there are significant differences when compared to the control class. The results agree with the concept of movement education which is one of the physical education learning models that emphasizes the concept of movement to help children develop fundamental movements, especially for elementary school students [8].

Movement education is child-centered, an approach to movement education that applies learning about movement elements such as time, effort and space. The results of the study show that movement education are more effective in developing creative abilities than formal methods [16]. The main view of movement education, in the field of sports science and movement education, in reality is very important to increase the activeness of children in participating in various activities to provide effective efficient education through the function of educational methods used in the teaching and learning [9]. In another research show that those who get movement education learning models are significantly better at throwing and running than those who have traditional learning [16].

Gross motor development is an important element to be developed in accordance with chronological age so that children will not be difficult to engage in more complex motor behavior at a higher age. Motoric is a fundamental movement skill, so it can be concluded that teaching that can develop FMS must be applied as early as possible. FMS has a variety of complexities, especially in terms of repetitive movements and sequential movements using the gross motor skills of children. In addition, the development of FMS for children varies according to their age level. The curriculum content that comes from the movement framework helps students develop competency in locomotor skills (skipping, running, hopping, galloping, sliding, leaping, jumping, and landing); and manipulative skills (striking, collecting, carrying, catching, throwing, kicking, dribbling, and volleying). Competency in games, gymnastics, and dance requires students to apply and improve these body skills, while responding to spatial demands, varying effort, and maintaining appropriate relationships to others and things [11]. Long time ago, another research was reported the import and role of movement educating between mind and body [17,18]. Based on the research reports, regarding how children learn is through understanding cognitive movement. So that movement is itself the essence of learning [19].

\section{CONCLUSION}

According to the research data during the research process on the application of movement education model in developing FMS in third grade elementary school students gave positive effect on improving FMS.

\section{ACKNOWLEDGMENT}

The authors wished to thank Universitas Pendidikan Indonesia for the financial support and to Widi Radiana and Wandi, Program Study PGSD Penjas for their cooperation and assistance in merging the data.

\section{REFERENCES}

[1] T.L. McKenzie, J.F. Sallis, S.L. Broyles, M.M. Zive, P.R. Nader, C.C Berry and J.J. Brennan, "Childhood movement skills: predictors of physical activity in Anglo American and Mexican American adolescents?" Research quarterly for exercise and sport, vol. 73, no. 3, pp. 238-244, 2002.

[2] A.D. Okely, M.L. Booth, and T. Chey, "Relationships between body composition and fundamental movement skills among children and adolescents,” Res. Q. Exerc. Sport, vol. 75, pp. 238-247, 2004.

[3] L.M. Barnett, P.J. Morgan, E. van Beurden, and J.R. Beard, "Perceived sports competence mediates the relationship between childhood motor skill proficiency and adolescent physical activity and fitness: A longitudinal assessment," Int. J. Behav. Nutr. Phys. Act., vol. 5, pp. 112,2008

[4] P.J. Morgan, L.M. Barnett, D.P. Cliff, A.D. Okely, H.A. Scott, K.E Cohen, and D.R. Lubans, "Fundamental Movement Skill Interventions in Youth: A Systematic Review and Meta-analysis," Pediatrics, vol. 132, no. 5, 2013.

[5] W. Chen, A. Hammond-Bennett, and A. Hypnar, "Examination of motor skill competency in students: Evidence-based physical education curriculum," BMC Public Health, vol. 17, no. 1, pp. 1-8, 2017.

[6] P.H. Werner, A movement approach to games for children. C.V Mosby Company, 1979.

[7] R. Wibowo, E. Nugraha and K. Sultoni, Fundamental Movement Skills and Game Performance in Invasion Game Activities, no. 229, pp. 390-5 2017.

[8] A. Mahendra, Model Pendidikan Gerak. Bandung: FPOK UPI, 2017.

[9] M. Altinkok, "The Effect Movement Education Based On Cooperative Learning Method On Development Of Basic Motor Skills Of Primary School 1st Grade Leaners," Journal of Baltic Science Education, vol. 16, no. 2, pp. 241-249, 2017.

[10] S. Kovar, C. Combs, K. Campbell, G. Owen, and V. Worrel, Elementary classroom teacher as movement educators. 2th edition. 2018

[11] T.W. Langton, “Applying Laban 's Movement Physical Education," vol. 78 , no. 1 , pp. 2007.

[12] O. Mazzardo, "The Relationship of Fundamental Movement Skills and Level of Physical Activity in Second Grade Children," Australian Association for Research in Education (AARE) International Conference, vol. 26, no. 1, pp. 71-79, 2008.

[13] F. Bardid, A. De Meester, L. Tallir, G. Cardon, M. Lenoir and L. Haerens, "Configurations of actual and perceived motor competence among children: Associations with motivation for sports and global selfworth," Human movement science, vol. 50, pp. 1-9, 2016.

[14] D.A. Ulrich, Test of Gross Motor Development- Second Edition. Austin, TX: Prod-Ed Publishers, 2000

[15] L.M. Barnett, D.R. Nicola, Z. Avigdor, and J. Salmon, "Face Validity and Reliability of a Pictorial Instrument for Assessing Fundamental Movement Skill Perceived Competence in Young Children," Journal of Science and Medicine in Sport, vol. 18, no. 1, pp. 98-102, 2015

[16] T. Toole and E. Arink, "Movement Education: Its Effect on Motor Skill Performance," Research Quarterly for Exercise and Sport, vol. 53, no. 2, pp. 156-162, 2015. 
[17] K. Calfas and W. Taylor, "Effects of Physical Activity on Psychological Variables in Adolescents," Pediatric Exercise Science, vol. 6, pp. 406423, 1994.
[18] G.V. Barton, K. Fordyce, and K. Kirby, "Why have physical education? The importance of the development of motor skills to children," Teaching Elementary Physical Education, vol. 10, pp. 9-11, 1999.

[19] C. Summerford, "PE-4-ME: Teaching lifelong health and fitness," Human Kinetics, 2000. 